University of Chicago Law School

Chicago Unbound

Journal Articles

Faculty Scholarship

1983

\title{
The Direct and Collateral Estoppel Effects of Alternative Holdings
}

Jo Desha Lucas

Follow this and additional works at: https://chicagounbound.uchicago.edu/journal_articles

Part of the Law Commons

\section{Recommended Citation}

Jo Desha Lucas, "The Direct and Collateral Estoppel Effects of Alternative Holdings," 50 University of Chicago Law Review 701 (1983).

This Article is brought to you for free and open access by the Faculty Scholarship at Chicago Unbound. It has been accepted for inclusion in Journal Articles by an authorized administrator of Chicago Unbound. For more information, please contact unbound@law.uchicago.edu. 


\title{
The Direct and Collateral Estoppel Effects of Alternative Holdings
}

\author{
Jo Desha Lucas $\dagger$
}

Under long accepted principles, a valid final judgment on the merits bars a subsequent suit on the same cause of action by a party or a person privy ${ }^{1}$ to the record. ${ }^{2}$ In addition, such a judgment estops parties and their privies from relitigating in a subsequent action an issue that was (1) actually litigated and determined, ${ }^{3}$ if (2) the determination was essential to the judgment, and (3) the person against whom the estoppel is pleaded had a full and fair opportunity to litigate the issue. ${ }^{5}$ Applying these principles, courts generally have held that a determination that does not logically support the judgment is not essential and may be relitigated in a subsequent suit on a different cause of action. ${ }^{6}$ This principle has been rested on a number of grounds. The first is that a finding of fact or the determination of an issue that does not

$\dagger$ Arnold I. Shure Professor of Law, University of Chicago.

1 The Restatement (Second) of Judgments avoids the term "privity" in favor of the concept of "representation." See 2 Restatement (SEcond) or Judgments at 13-14 \& §63 (1980). For present purposes, however, the distinction is irrelevant. See J. MoorE \& T. CURRIBr, 1B Moore's Frderal Practice I 0.411[1] (2d ed. 1982), for a general discussion of privity and mutuality.

2 Restatement (Second) of Judgments $\$$ 17, 27, 29 (1980).

- Id. § 27; see J. MOORE \& T. CURRIER, supra note 1, \0.443[3].

- Restatement (Second) of Judgments $\$ 27$ (1980); see J. Moore \& T. Currier, supra note $1, \pi 0.443[5]$.

- The "full and fair opportunity" principle originates, in the federal courts, in BlonderTongue Laboratories, Inc. v. University of Ill. Found., 402 U.S. 313, 328 (1971). Some element of fair opportunity to litigate is a necessary ingredient of procedural due process, but the Supreme Court has indicated that "full and fair opportunity," as applied in the federal courts to mark the limits of collateral estoppel invoked by a stranger to the first litigation, extends beyond this minimum. In Parklane Hosiery Co. v. Shore, 439 U.S. 322 (1979), the Court permitted the offensive use of collateral estoppel by a stranger to the first litigation, but noted that offensive use of collateral estoppel is inappropriate where the party seeking to use the prior judgment offensively could easily have joined the earlier action or where collateral estoppel would be unfair to the party against whom the prior judgment is sought to be used. Id. at 329-33. Cf. Kremer v. Chemical Constr. Corp., 456 U.S. 461, 480-83 (1982), in which the Court drew a distinction between a federal district court's discretion to reject collateral estoppel as unfair in the case of judgments rendered in the federal courts and its duty under 28 U.S.C. $\$ 1738$ (1976) to apply the state law of res judicata and estoppel in the case of judgments rendered by the state courts.

- J. Moore \& T. Currier, supra note 1, $\mid$ 0.443[5]. 
support the judgment is not a part of the court's judgment, but analogous to a dictum. ${ }^{7}$ The second is that a nonessential finding is unreliable because it may have been made with less scrutiny than it would have received if the result had depended upon it. ${ }^{8}$ Third, such findings generally are not appealable. ${ }^{9}$

Cases involving nonessential findings have been distinguished from those in which a judgment is supported by two or more determinations, each of which itself would be sufficient. Judgments resting on independently sufficient determinations arise in a number of circumstances. First, the plaintiff may pitch a single claim for relief on two or more legal theories, any one of which might justify the relief, and make his case on more than one. ${ }^{10}$ Second, the plaintiff might plead more than one instance of conduct giving rise to the claim and prove them all. ${ }^{11}$ Third, there are cases in which,

7 The analogy is not complete. A judgment applies the law to the facts as determined. A statement unrelated to the facts is in the nature of an abstract proposition. But the facts must be determined before the law can be applied to them, and so they can be characterized as unnecessary only by virtue of hindsight; their determination was necessary to arrive at a judgment, but as determined they do not support that judgment.

- See Irving Nat'l Bank v. Law, 10 F.2d 721, 724 (2d Cir. 1926). Whether any such general inference is proper is open to question. Often the thoroughness with which particular issues have been exposed and considered can be determined from the record and the court's opinion, and the limitation of estoppel to such determinations as support the judgment may reflect to some extent the assumption that the doctrine of collateral estoppel is to be mechanically applied except in the case of some categorical exception. After the decision in Blonder-Tongue Laboratories, Inc. v. University of Ill. Found., 402 U.S. 313 (1971), this assumption is questionable. But the requirement that the finding be necessary to the judgment has been consistently adhered to. See, e.g., Parklane Hosiery Co. v. Shore, 439 U.S. 322,326 n.5 (1979).

- Normally a party may not appeal from a judgment in his favor to review findings he believes to be erroneous but which are not necessary to support the decree. See J. Moore \& T. Currier, supra note $1,10.443$ [5], at 3923-25. But when this general proposition is used to support the principle that such a finding may not be used to support a collateral estoppel, it has a certain chicken/egg aspect: if the finding is not conclusive, the prevailing party is not a party aggrieved and, therefore, has no standing to appeal; if the prevailing party can appeal, the finding should be deemed conclusive. $C f$. Electrical Fittings Corp. v. Thomas \& Betts Co., 307 U.S. 241 (1939) (holding that defendant could appeal from a decree holding plaintiff's patent valid but not infringed, appeal being allowed for the limited purpose of reforming the decree to eliminate the portion holding the patent valid); United Aircraft Corp. v. NLRB, 440 F.2d 85, 99 (2d Cir. 1971) (applying collateral estoppel to a determination of the NLRB adverse to the prevailing party but as to which the prevailing party could have obtained review).

${ }^{10}$ See, e.g., Kaiser Indus. Corp. v. Jones \& Laughlin Steel Corp., 515 F.2d 964, 980-87 (3d Cir.), cert. denied, 423 U.S. 876 (1975).

11 For example, under the Bankruptcy Act of 1898, ch. 541, 30 Stat. 544 (1898) (repealed 1978), the petitioner might allege two or more acts of bankruptcy, any of which, if proved, would suffice.

In suits for injunctions, separate acts have been considered as cumulative rather than independently sufficient. See, e.g., Tanker Hygrade No. 18, Inc. v. United States, 526 F.2d 
to prevail, the plaintiff must establish two distinct elements of his claim, and he establishes neither. ${ }^{12}$ Fourth, the defendant may deny the allegations of the complaint and also raise an affirmative defense, or plead more than one compatible defense and prevail on two or more such issues. ${ }^{13}$

There is a surface analogy between such independently sufficient determinations and those that are not essential to the judgment. Each determination, taken alone, is not essential to the judgment in one sense of the word, for a contrary decision of any one singly would not alter the outcome. But with respect to the reasons for denying preclusive effect to nonessential determinations, they differ on all three scores. The analogy to stare decisis fails; multiple grounds for decision are not dicta. Since each disposition is dispositive independently, there is no reason why the parties, the judge, or the jury might be expected to regard it as unimportant or give it less than its due measure of scrutiny. ${ }^{14}$ Moreover, all of the determinations are reviewable on appeal. Thus, under traditional principles, a judgment resting on two or more independently sufficient grounds precludes relitigation of any of them.16

For two reasons in combination, the question of collateral estoppel to preclude relitigation of findings independently sufficient to support a judgment has not, until recent years, produced very much litigation..$^{10} \mathrm{~A}$ relatively broad concept of cause of action and the compulsory counterclaim rules limit sharply the circumstances in which the issue can arise in subsequent litigation between the parties, and so long as most jurisdictions adhered to the requirement of mutuality of collateral estoppel, a stranger to the litigation could rarely plead it. ${ }^{17}$ This paper addresses recent developments

805, 810-12 (Ct. Cl. 1975) (a decision based on the cumulative effect of several oil spills precludes relitigation of individual spills), cert. denied, 426 U.S. 920 (1976).

12 The illustration given in RESTATEMENT OF JUDGMENTS $\$ 68$ comment $n$, illustration 8 (1942), is the case in which a judgment is rendered for the defendant in a personal injury action on specific findings that defendant was not negligent and plaintiff was guilty of contributory negligence.

13 There are many theoretical examples, as the defendant will often deny the allegations of the complaint and interpose one or more affirmative defenses.

14 See Massachusetts v. United States, 333 U.S. 611, 617-23 (1948).

${ }^{15}$ See, e.g., Trone v. Smith (In re Westgate-California Corp.), 642 F.2d 1174, 1176-77 (9th Cir. 1981); Winters v. Lavine, 574 F.2d 46, 66-67 (2d Cir. 1978); Williams v. Ward, 556 F.2d 1143, 1154 (2d Cir.), cert. dismissed, 434 U.S. 944 (1977); Irving Nat'l Bank v. Law, 10 F.2d 721, 724 (2d Cir. 1926); First Nat'l Bank v. Covington, 129 F. 792,797 (C.C.E.D. Ky. 1903), aff'd, 198 U.S. 100 (1905); 420 Mining Co. v. Bullion Mining Co., 9 F. Cas. 592, 597600 (C.C.D. Nev. 1876) (No. 4989).

18 See Halpern v. Schwartz, 426 F.2d 102, 107 n.4 (2d Cir. 1970).

17 The Restatement (Second) abandons the concept of a "cause of action" and applies 
regarding the effect of alternative holdings on subsequent litigation involving one or both parties to the original suit.

\section{Halpern v. Schwartz}

In 1970, in Halpern v. Schwartz, ${ }^{18}$ the Court of Appeals for the Second Circuit reexamined the question of estoppel by a judgment supported by more than one independently sufficient finding and concluded that in such a case neither finding should afford the basis for a collateral estoppel. ${ }^{19}$

The first proceeding in the Halpern case was on a petition to adjudicate man and wife involuntary bankrupts. The respondents were shareholders in a family business, and the petition charged that the assignment of a mortgage and bond to the respondents' son constituted an act of bankruptcy under two separate subsections $^{20}$ of the Bankruptcy Act of $1898 .{ }^{21}$ Under one of these it was unnecessary to prove actual intent to defraud creditors. Under the other, proof of such intent was required. ${ }^{22}$ The wife did not testify

the doctrine of bar to the same "claim." The term "claim" is defined to include "all rights of the plaintiff to remedies against the defendent with respect to all or any part of the transaction, or series of connected transactions, out of which the action arose." RESTATEMENT (SECOND) OF JUDGMENTS \& 24(1) (1980). The term "transaction, or series of connected transactions" is left "to be determined pragmatically, giving weight to such considerations as whether the facts are related in time, space, origin, or motivation, whether they form a convenient trial unit, and whether their treatment as a unit conforms to the parties' expectations or business understanding or usage." $I d$. $\$ 24(2)$. Although the federal courts have, perhaps, not gone as far, the trend toward a broader concept of "claim" in the context of bar and merger has been noted by the Supreme Court. See Blonder-Tongue Laboratories, Inc. v. University of Ill. Found., 402 U.S. 313, 327 (1971).

The transactional theory of a claim has been a feature of the compulsory counterclaim rule since its promulgation in 1939. See FED. R. Crv. P. 13(a).

The requirement of mutuality as a condition to collateral estoppel was not abandoned by the Supreme Court until 1971 in Blonder-Tongue Laboratories. The Court did not give specific sanction of affirmative use of collateral estoppel by a stranger to the prior litigation until 1979 in Parklane Hosiery Co. v. Shore, 439 U.S. 322 (1979).

18 426 F.2d 102 (2d Cir. 1970).

19 Id. at 106.

so The petitioners alleged that the respondents

(1) conveyed, transferred, concealed, or removed valuable property with intent to hinder, delay and defraud their creditors (an act of bankruptcy under section $3 a(1)$ of the Bankruptcy Act ["Act"], 11 U.S.C. \$ 21(a)(1)); and (2) transferred valuable property while insolvent to creditors with the intent to prefer such creditors over others of the same class (an act of bankruptcy under section $3 a(2)$ of the Act, 11 U.S.C. §§ 21(a)(2), 96).

426 F.2d at 103.

21 Pub. L. No. 55-171, 30 Stat. 544 (repealed 1978).

22 Strictly speaking, $\S 3 a(1)$ of the amended Bankruptcy Act of 1898 did not require proof of intent to defraud. That provision, as codified, referred to "having (1) concealed. . . or removed any part of [the bankrupt's] property, with intent to hinder, delay, or defraud 
or appear at the trial. The court heard testimony, including the testimony of the husband, and found that an act of bankruptcy had taken place on three statutory grounds. ${ }^{23}$ The respondents were adjudicated bankrupts and the case was referred. The respondents took joint appeals, arguing that the evidence was insufficient to establish the transfer, but did not argue the issue of intent. The court of appeals affirmed from the bench without opinion. ${ }^{24}$

Four years later, the wife applied for a discharge. The trustee moved for summary judgment denying discharge, contending that the earlier finding that the bankrupts had removed assets of the estate with the intent to delay collection put the issue of discharge beyond triable issue of fact. The district court granted the motion, and the wife appealed. The court of appeals reversed, holding that the first judgment did not estop the wife from denying intent in the discharge proceeding because the previous findings of an act of bankruptcy independent of intent under two subsections made the determination of intent unnecessary to the judgment. ${ }^{25}$

Judge Smith took occasion to review the cases espousing the doctrine that independently sufficient determinations made in support of a judgment are each conclusive, found the doctrine not so firmly established as to preclude reexamination, and on the merits found it wanting. First, he found persuasive the analogy to determinations that are "incidental, collateral or immaterial" to the judgment. ${ }^{28}$ Since in neither case does the relief depend upon the determination, there is a risk of substandard consideration of individual grounds. In the particular case, for example, he questioned whether, in view of the two grounds for treating the transfer as an

his creditors or any of them, or made or suffered a transfer of any of his property, fraudulent under the provisions of section 107 or 110 of this title." 11 U.S.C. $§ 21(\mathrm{a})(1)$ (1976) (repealed 1978). Under § 107, which dealt with fraudulent transfers, the transfer could have been fraudulent without proof of intent to defraud. See id. $\$ 107(d)$. Nevertheless, the petition charged the first alternative under $\S 3 a(1)$. Section $3 a(2), 11$ U.S.C. $\S 21(a)(2)$ (1976) (repealed 1978), dealt with preferences and required intent to prefer, but did not require proof of specific intent to defraud.

23 According to the Second Circuit, the district court found the assignment to be an act of bankruptcy because

(1) it was a removal of property with intent to hinder and delay creditors under section $3 a(1)$ of the Act; (2) it was a transfer of property under section $3 a(1)$, fraudulent as to creditors as defined in section 67 of the Act, 11 U.S.C. $\$ 107(d)(2)$; and (3) it was a preferential transfer of property under section $3 a(2)$ as defined in section 60 of the Act, 11 U.S.C. $\$ 96$.

426 F.2d at 103.

24 In re Halpern, Nos. 29704-05 (2d Cir. June 10, 1965) (affirmed without opinion).

38 Halpern v. Schwartz, 426 F.2d at 108.

26 Id. at 105. 
act of bankruptcy independent of intent, the district judge gave the issue of the wife's intent the scrutiny it would have received had it been a linchpin to the relief. ${ }^{27}$

Second, although he conceded that all independent grounds for a judgment are reviewable on appeal, he thought that in cases decided on the basis of more than one independently sufficient determination the losing party might be deterred from seeking review of any particular ground when affirmance of the judgment on an alternative ground appears probable. ${ }^{28} \mathrm{He}$ took the effect of affirmance on one ground without reaching the other to be in some doubt. $^{28}$

Even in cases in which there is an appeal, he believed that adequate review of any particular determination might be deterred. In the Halpern case itself, he pointed out, the necessity to resist all three determinations on appeal apparently led the respondents to concentrate on the argument that the transfer did not take place, since this defense would relate to all three grounds for the judgment. ${ }^{30} \mathrm{He}$ also suggested that appellate consideration of a particular ground might be affected by want of the usual adversary presentation because the appellee might be expected to concentrate on the strongest basis for affirmance or the cumulative nature of the grounds. ${ }^{31}$

Further, he argued that in cases in which one ground is unassailable, the traditional rule would encourage appeals for the sole purpose of forestalling the pleading of an estoppel in collateral litigation. Judge Smith found such appeals undesirable, for they place a present burden on appellate courts in exchange for speculative savings in the time of courts of first instance, since, after all, collateral litigation might not arise. ${ }^{32}$

27 Id.

2o Id. at 105-06.

29 The Restatement (Second) takes the position that in the case in which the judgment is appealed and the appellate court affirms on one ground and does not reach the other, the judgment constitutes a basis for collateral estoppel only on the ground on which the affirmance rests. RESTATEMENT (SECOND) of JUDGMENTS § 27 comment o (1980). This view has support in the federal cases. See, e.g., Plastic Container Corp. v. Continental Plastics, 607 F.2d 885, 893-98 (10th Cir. 1979), cert. denied, 444 U.S. 1018 (1980); Stebbins v. Nationwide Mut. Ins. Co., 528 F.2d 934, 936-38 (4th Cir. 1975), cert. denied, 424 U.S. 946 (1976). Comment o does not deal, however, with the case in which the judgment is affirmed without opinion.

so 426 F.2d at 106-07.

sI Id. at 106 \& n.2.

s2 Id. at 106. 


\section{Halpern v. Schwartz and The Restatement (Second)}

In 1977, when Tentative Draft No. 4 of the Restatement (Second) of Judgments ${ }^{33}$ was published, Halpern v. Schwartz ${ }^{34}$ represented the most recent judicial examination of the question of the effect of judgments resting on independently sufficient grounds, and the reporters found themselves "persuaded by its reasoning,"35 which they applied both to the doctrine of bar (claim preclusion in the parlance of the new Restatement) and to the doctrine of collateral estoppel (issue preclusion).

\section{A. The Doctrine of Bar}

Section 19 of the Restatement (Second) states the conventional rule that "[a] valid and final personal judgment rendered in favor of the defendant bars another action by the plaintiff on the same claim."3s Section 20 states a number of exceptions to this general proposition. ${ }^{37}$ Subsection (1) of section 20 lists a number of classes of dismissals ordinarily viewed as not disposing of the claim on the merits. ${ }^{38}$ Subsection (2) provides:

A valid and final personal judgment for the defendant, which rests on the prematurity of the action or on the plaintiff's failure to satisfy a precondition to suit, does not bar another action by the plaintiff instituted after the claim has matured, or the precondition has been satisfied, unless a second action is precluded by operation of the substantive law. ${ }^{39}$

Comment (e) to section 20 applies the Halpern reasoning to indicate that a dismissal by a court of first instance based upon two or more determinations, at least one of which, standing alone, would not render the judgment a bar to another action on the same claim, should not operate as a bar. ${ }^{40}$ This principle is illus-

33 Restatement (Second) of Judgments (Tent. Draft No. 4, 1977).

34426 F.2d 102 (2d Cir. 1970).

35 Restatemant (Second) of Judgments § 27 comment i, reporter's note (1980).

36 Id. § 19.

${ }^{27}$ Id. $\S 20$. The Restatement (Second) abandons the concept of a judgment "on the merits." See id. $\$ 19$ comment a. Instead, it states the rule of bar baldly in $\S 19$, and then states exceptions in $\S 20$. See id. $\S 19$ comment a. Cf. Restatrment of Judgments $\$ 48$ (1942) (stating that judgment on the merits for defendant bars plaintiff from maintaining another action on the original cause of action).

ss Restatement (Second) of Judgmints § 20(1) (1980). Cf. Fed. R. Crv. P. 41(b) (the effect of involuntary dismissal generally is the same as that of judgment on the merits unless dismissal is without prejudice).

so Restatement (Second) of Judgments § 20(2) (1980).

${ }^{10}$ Id. $\S 20$ comment e, reporter's note. 
trated by the case in which $A$ sues $B$ for breach of contract and the court enters judgment for $B$ after determining (1) that the contract is unenforceable because not in writing, (2) in any event $B$ was induced to enter into the contract by $A$ 's fraud, and (3) the action is premature because the time for $B$ 's performance has not yet arrived. ${ }^{41}$ The effect of the same determination made by an appellate court is left in some doubt. ${ }^{42}$

The position of the Restatement (Second) at least conceivably derives from the treatment of a judgment for the defendant based both on want of jurisdiction of the subject matter and on the merits. In those circumstances the judgment does not bar a new suit in another jurisdiction. This rule is logical and uncontroversial, for the unappealed determination of want of jurisdiction renders the determination of the merits subject to collateral attack. ${ }^{43}$ The case

\footnotetext{
41 Id. $\S 20$ comment e, illustration 4.

42 If the judgment resting on alternative determinations discussed in the preceding paragraph is that of an appellate court, the question whether it bars another action on the same claim is a difficult one. See the discussion of an analogous question on [sic] the context of issue preclusion, $\S 27$, Comments $i$ and $o$. But in any event, the judgment should not operate as a bar if one of the determinations is that the court in which the action was brought lacked subject matter or personal jurisdiction to adjudicate the claim.
}

Id. $\S 20$ comment e. Such cases might be inordinately rare.

43 Cf. International Philanthropic Hosp. Found. v. United States, 621 F.2d 402, 405 (Ct. Cl. 1980), where a dismissal by a district court with prejudice on a finding of want of jurisdiction of the subject matter was read by the Court of Claims as meaning with prejudice to refiling in the district court, and McLearn v. Cowen \& Co., 660 F.2d 845 (2d Cir. 1981), in which Judge Lumbard expressed the opinion that a judgment dismissing plaintiff's action pleaded under federal law with a pendent claim under state law was void insofar as it purported to dismiss the pendent claim on the merits. He proceeded on the theory that a federal court that dismisses the federal claim before trial and before it has committed substantial time and effort to the state law claim is without subject matter jurisdiction to dispose of the state law claim on the merits. Id. at 848-49. Judge Lasker disagreed, but concurred in the result on the ground that relief could be based on FED. R. Crv. P. $60(\mathrm{~b})(6) .660$ F.2d at 849, 851. Judge Meskill dissented. Id. at 852. The McLearn case illustrates the point that the distinction between a jurisdictional dismissal and one on the merits is not always without difficulty.

A judgment on the merits joined with a determination of improper venue or want of jurisdiction of the person may lead to different results. The defendant can waive objection to these defects, see 28 U.S.C. § 1406(b) (1976); FED. R. CIv. P. 12(h)(1), and the plaintiff, having chosen the time and place for judgment, should not be heard to complain about the judgment he gets. Under FED. R. CIV. P. 12(b), objections to personal jurisdiction and venue may be made by motion or in the answer, but whichever way they are made they are usually disposed of in advance of trial. See FED. R. Crv. P. 12(d). In some states, such objection must be made prior to answer. See, e.g., Code of Civil Procedure § 2-104(b), ILL. REv. Stat. ch. 110, I 2-104(b) (1983) (wrong venue, waiver, motion to transfer); id. § 2-301, ILL. REv. STAT. ch. 110, I 2-301 (1983) (special appearance). In the federal practice, it is possible to present in a single motion objections to jurisdiction or venue and objection for failure to state a claim on which relief can be granted. When this is done, and the motion is granted, 
of a defense of failure to perform conditions precedent, where the condition is a statutory precondition to suit, is closely analogous to the case where lack of subject matter jurisdiction is shown, for a finding of failure to satisfy the statutory precondition is a finding that the suit cannot be maintained. Moreover, judgment for the defendant based upon failure to satisfy the precondition and upon the merits has the same contradictory character as has a judgment on the merits where the court lacks jurisdiction to determine the merits. ${ }^{44}$

The defense of failure to satisfy a substantive condition to liability (i.e., the defense of prematurity) differs, however, from the subject matter jurisdiction defense. The prematurity defense goes to the present existence of a cause of action, not to the power of the court to render a judgment on the action, should one exist. A consideration of the procedural treatment of these defenses will help explain the shortcomings of the Restatement (Second) position regarding the doctrine of bar in cases where a finding of prematurity is coupled with other independently sufficient bases of judgment.

The procedural system, and indeed the doctrines of bar and estoppel, are guided by concerns for fairness and efficiency. Under the Federal Rules of Civil Procedure, the defendant may raise in his answer as many defenses, legal or equitable, as he may care to interpose, but affirmative defenses must be pleaded. ${ }^{45}$ Certain defenses, at the option of the pleader, may be raised by motion prior to answer, ${ }^{46}$ and these defenses, whether raised by motion or answer, will be heard in advance of trial on request of any party, unless the court orders otherwise. ${ }^{47}$ This procedure obviously contemplates that both parties will give notice of their claims and defenses and that unless fairness or convenience dictate otherwise, the whole controversy will be settled by one trial and one appeal. ${ }^{48}$ This end is aided by Rule 41(b) (patterned after the pre-Rules equity practice), which, with stated exceptions, treats an involuntary

the basis of the dismissal could become a matter of dispute, but a dismissal rested explicitly on both grounds is unlikely.

4 See Costello v. United States, 365 U.S. 265, 284-88 (1961); Stebbins v. Nationwide Mut. Ins. Co., 528 F.2d 934, 937-38 (4th Cir. 1975), cert. denied, 424 U.S. 946 (1976).

4s Fed. R. Civ. P. 8(c).

16 Id. 12(b).

17 Id. 12(d).

48 Except for those defenses determined on motion or preliminary hearing under Rule 12(b), (d), all issues to be resolved by the trial of contested facts are to be presented at a single trial unless, under Rule $42(\mathrm{~b})$, the court orders separate trials. 
dismissal as a judgment on the merits unless the court specifies that it is without prejudice. ${ }^{49}$

When one defense is temporary in nature and another will bar the underlying claim, it would be possible to require that the less preclusive defense be tried first and, if successful, that the more inclusive defense be left for determination in another suit on another day. In some cases this would conserve judicial resources, for the parties might settle their differences before that day arrived, and if they did, the court would not have to address what would usually be the more complex issues. But any saving that would be made in such cases would have to be balanced off against the time consumed in successive appeals. In the Restatement illustration, ${ }^{50}$ for example, if the trial court decided the issue of prematurity and declined to address the issues of statute of frauds and fraud, and the plaintiff appealed, reversal by the appellate court would return the case for trial of the pretermitted issue, and the judgment after trial would in turn be appealable. ${ }^{51}$

A different way to deal with sequential defenses would be to require trial of all issues and then entry of judgment on one ground at a time, but this scheme would be even more at odds with efficiency, for it would invite successive appeals without any compensating saving. ${ }^{62}$ Ideally, then, if a finding of prematurity would

40 FED. R. Crv. P. 41(b). The stated exceptions are "a dismissal for lack of jurisdiction, for improper venue, or for failure to join a party under Rule 19." Id. As we have seen, dismissal for failure to satisfy a statutory precondition to suit has been held to be a dismissal for "lack of jurisdiction" for purposes of Rule 41(b). See Costello v. United States, 365 U.S. 265, 285 (1961). There is language in Costello suggesting that other bases for dismissal, that, like prematurity, do not address the merits might also be so considered. Id. at 285-86. It is extremely risky, however, to forgo an appeal on the assumption that a judgment on the merits within the literal terms of Rule 41 (b) will not bar a second action. See, e.g., Cemer v. Marathon Oil Co., 583 F.2d 830 (6th Cir. 1978); Weissinger v. United States, 423 F.2d 795, 798-800 (5th Cir. 1970).

so See supra note 41 and accompanying text.

s1 In the case of dismissals under FED. R. CIv. P. 12(b), of course, this is the practice.

${ }^{82}$ In this connection it should be noted that the Restatement (Second) formulation addresses solely the question of the effect of the judgment when it is based on two grounds. It does not deal with the case in which the court bases the judgment on one ground and declines to reach the other. Thus in the Restatement (Second) illustration there exists the possibility that the court might render its judgment solely on the ground either of the statute of frauds or fraud in the inducement and indicate that since the contract was unenforceable ab initio there is no necessity to determine whether the time for performance has arrived. Unless this would be reversible error, the Restatement (Second) rule on multiple grounds serves only as an aid to interpreting the judgment, permitting the plaintiff to read it, so to speak, in mitiori sensu. The time for appeal is short, and the consequences of failing to appeal are drastic. See, most recently, Federated Dep't Stores, Inc. v. Moitie, 452 U.S. 394 (1981), which held that res judicata bars relitigation of an unappealed adverse judgment, where other plaintiffs in similar actions against the same defendant successfully 
preclude a judgment on a ground that would bar a second action, the prematurity issue should be disposed of first, and the court should not try the merits. But this is not within the design of the Rules. Prematurity, as such, is not a defense that can be raised by motion prior to answer, ${ }^{53}$ unless the prematurity appears on the face of the complaint. ${ }^{54}$ Nor is it a defense that is to be resolved at a preliminary hearing. ${ }^{.5}$ If it does not depend upon contested facts, it can be determined on motion for summary judgment, ${ }^{56}$ and the court may order a separate trial on the issue, ${ }^{87}$ but in the normal course of events it will be proved at trial along with such other defenses as may have been raised. ${ }^{58}$

The fairness and efficiency of this procedure is nowhere more apparent than in the case posed by the Restatement (Second) illustration above. ${ }^{50}$ The plaintiff sued for breach of contract. The defendant pleaded three defenses: the statute of frauds, fraud in the inducement, and prematurity. Raising all three defenses is

appealed judgments against them. See also Ackerman v. United States, 340 U.S. 193 (1950) (holding that where plaintiffs had failed to appeal denaturalization judgment, they could not later file a motion to set aside cancellation of their certificates of naturalization, pursuant to Fed. R. Crv. P. 60(b)). Fed. R. Crv. P. 41(b) and 58 are meant to simplify the task of identifying a judgment and its effect. If an action is dismissed with prejudice when it should be dismissed without prejudice, the error is correctable on appeal. See, e.g., Caldwell v. Camp, 594 F.2d 705, 708 (8th Cir. 1979) (reversing a district court's dismissal with prejudice). The Restatement (Second) rule, therefore, does not serve to simplify identification; it complicates the inquiry.

33 Those that can be raised prior to answer include the following: "(1) lack of jurisdiction over the subject matter, (2) lack of jurisdiction over the person, (3) improper venue, (4) insufficiency of process, (5) insufficiency of service of process, (6) failure to state a claim upon which relief can be granted, (7) failure to join a party under Rule 19." FBD. R. Crv. P. 12(b).

so It may be assumed that if prematurity appears from the complaint, the issue can be raised by motion to dismiss under Rule 12(b)(6). See Oregon-Washington Water Serv. Co. v. City of Hoquiam, 29 F.2d 566 (9th Cir. 1928) (decided under former Equity Rule 29, prior to the adoption of the FBD. R. Crv. P.).

ss FeD. R. Crv. P. 12(d).

so Id. 56(a), (b).

${ }^{87}$ Id. $42(\mathrm{~b})$.

ss In the Restatement (Second) illustration, this would be almost necessarily so, because the contract is oral and the question would depend upon proof of its terms. See RESTATEMENT (Second) of Judgments $\$ 20$ comment e, illustration 4 (1980).

Although the court could dispose of the case on one ground and not reach the other, disposition on the least important ground is not favored. See, e.g., Sinclair \& Carroll Co. v. Inter-Chemical Corp., 325 U.S. 327, 330 (1945), where the Supreme Court noted a tendency on the part of the lower courts in patent infringement cases to dispose of the proceedings on the issue of infringement where possible, without reaching the issue of validity. The Court noted that the better practice is to reach the more important issue.

so See supra note 41 and accompanying text. 
proper and, indeed, necessary. ${ }^{\circ 0}$ The plaintiff, in suing for breach of contract, must necessarily be prepared to meet defenses under the statute of frauds and based on fraud in the inducement. The defense that the time for performance has not arrived is in essence a denial that any breach has taken place. If the plaintiff is willing to concede this issue, he may move for a voluntary dismissal. ${ }^{61}$ If the issue does not rest on contested facts, he may move for a partial summary judgment. ${ }^{62}$ If justice requires resolution of the issue ahead of others, he may request a separate trial. ${ }^{63}$ If he goes to trial on all three issues, presents his evidence on all three issues, and loses on all three issues, he has had a full and fair opportunity to litigate. If he is dissatisfied with the judgment, he has a right to appeal, and on appeal he can attack all three grounds for the judgment, or he can concede prematurity and attack the grounds going to the underlying contract. ${ }^{84}$ There is no unfairness to the plaintiff, then, in treating the judgment as a bar.

Nor do the reasons assigned in Halpern $v$. Schwartz and

so The defenses of fraud and the statute of frauds are affirmative defenses under FrD. R. Crv. P. 8(c). If the defendant had not pleaded them and lost on the issue of prematurity, he would be cast in judgment and his defenses would be forever lost. If he had omitted the prematurity defense and lost on the other two defenses, he would be cast in judgment for damages and would lose his option to perform his duties under the contract.

or See FED. R. Crv. P. 41(a).

${ }^{62}$ See id. 56(c).

os See id. 42(b).

a4 FED. R. ApP. P. 3(c) provides specifically for identification in the notice of appeal of a part of the judgment or order.

Account must be taken of the constitutional requirement of a live case or controversy between the parties. Thus it has been held that in a patent infringement suit in which the court has determined that there was no infringement and also that the patent was invalid, and the plaintiff has let the determination of no infringement stand and appealed only from the portion of the judgment finding the patent invalid, the appeal will be dismissed for mootness since the defendant has no interest in the outcome. Hall v. U.S. Fiber \& Plastics Corp., 476 F.2d 418, 420-21 (3d Cir. 1973). The court in Hall declined to vacate the finding of invalidity and indicated that the question of effect as a collateral estoppel under BlonderTongue Laboratories would have to await presentation of the issue in a second suit. Id. at 420. See also Cover v. Schwartz, 133 F.2d 541, 545 (2d Cir. 1942) (once the court finds against plaintiff on issue of patent infringement, it cannot go on to find in his favor on the issue of validity because of a lack of case or controversy).

When both determinations are appealed, of course this question does not arise. See, e.g., Sinclair \& Carroll Co. v. Inter-Chemical Corp., 325 U.S. 327, 330 (1945), in which the district court found no infringement and that the patent was invalid, the court of appeals reversed, holding the patent valid and infringed, and the Supreme Court in turn reversed the court of appeals, holding the patent invalid. Although in cases like Hall and Cover the defendants can be said to have no continuing interest in the validity of the patent, it can hardly be said that the defendant has lost his adversary position on the issues of the validity and enforceability of the contract in the Restatement (Second) example considered in text. 
found persuasive by the Restatement (Second) reporters ${ }^{65}$ fit the case. The statute of frauds and fraud in the inducement are not only affirmative defenses ${ }^{86}$ but in pleading the fraud defense, the circumstances constituting fraud must be stated with particularity. ${ }^{67}$ Thus both parties and the court are fully aware that the enforceability of the contract has been put in issue. The three defenses are wholly distinct and rest on different facts. There is no chance whatever that the court will decide the statute of frauds and fraud issues intersticially or treat them as unimportant. ${ }^{68}$

There appears to be no chance whatever that a plaintiff who has had his contract declared totally unenforceable under the statute of frauds, or on a finding of fraud in the inducement, would forgo an appeal because he fears that the appellate court might affirm the judgment on the ground of prematurity of the suit and not reach the other issues..$^{89}$ Even though the plaintiff, as appellant, would prefer reversal and remand for assessment of damages, he would seek in the alternative a remand with instructions to vacate the findings and dismiss without prejudice. ${ }^{70}$

It is also wholly unlikely that the issue of the statute of frauds and fraud in the inducement would appear in other than an adversary posture on appeal. A defendant who has obtained a judgment releasing him from the contract could hardly be expected to retreat on appeal to an argument that the suit was premature. The prematurity argument is plainly no more than a fall-back position to both appellant and appellee.

The Halpern-Restatement (Second) argument on judicial economy $^{71}$ is no more convincing. Imposing a bar should not in-

cs See supra notes 18-35 and accompanying text.

os See FrD. R. Crv. P. 8(c).

${ }^{67}$ Id. 9 (b).

es A judge who could not appreciate the distinction between prematurity and a statute of frauds or fraud in the inducement could not (to borrow a phrase attributed to the late President Johnson) "walk and chew gum at the same time." Nor is the distinction one that could confuse a jury.

- Despite doubts expressed on the subject in Halpern v. Schwartz, 426 F.2d 102, 105 (2d Cir. 1970), it is probably true that the affirmance of the judgment on the ground of prematurity, without reaching the issues of the statute of frauds and fraud in the inducement, would have the effect of converting the decision into one that would not bar a new suit at the proper time. See, e.g., Stebbins v. Nationwide Mut. Ins. Co., 528 F.2d 934, 936-38 (4th Cir. 1976). But the question of the interpretation of the decision of the appellate court apart, there is no conceivable doubt about the power of the court of appeals or the Supreme Court to modify the judgment to place it on the determination of prematurity alone. See 28 U.S.C. § 2106 (1976).

70 The appellant also could seek modification of the judgment. See supra note 69.

72426 F.2d at 106. 
duce appeals purely for the purpose of forestalling an estoppel in collateral litigation, and the present burden on appellate courts will result in more than speculative savings in the courts of first instance. The plaintiff does not ask the court to vacate findings to avoid estoppel in merely speculative litigation on another claim. There is but one claim, and it has been decided squarely on its merits. Further, if the judgment is not a bar, the future litigation is not exactly speculative. A party who has obtained a judgment establishing his defense to an action for breach of contract is most unlikely to just pay up. Thus the second suit is practically foreordained. Moreover, if the court in the second suit should render judgment for the plaintiff, the score on the matter would be one to one, and appeal would be almost inevitable.

In sum, there is no unfairness to the plaintiff in disposing of the case he brought to the court on any ground and all grounds that were properly presented and fully and fairly litigated. On the other hand, the inequity to the defendant that would be produced by the Restatement (Second) formulation is palpable. The plaintiff has chosen the time and the place of the suit. He has forced the defendant to adduce his evidence on all defenses. There has been a plenary trial and it has been decided that the plaintiff's claim is without merit. Why, at the plaintiff's option, the defendant should be twice vexed because he has also been vexed early is, to say the least, obscure.

\section{B. Estoppel Inter Partes}

The Restatement (Second)'s application of the "reasoning" of Halpern $v$. Schwartz to the doctrine of collateral estoppel, or, in the parlance of the Restatement, "issue preclusion,"72 raises many of the same problems already discussed in connection with its application to the doctrine of bar. In some situations, the distinction is not easy to recognize. In Stebbins $v$. Keystone Insurance Co., ${ }^{73}$ the plaintiff brought an action under Title VII of the Civil Rights Act of 1964, ${ }^{74}$ alleging that the defendant had refused him employment because of his race. Defendant moved for summary judgment and in support of its motion provided affidavits stating that plaintiff had refused to file a written application for employment. It also relied upon statements in plaintiff's depositions to show that plain-

72 Restatement (Second) of Judgments $\$ 27$ (1980).

73 481 F.2d 501 (D.C. Cir. 1973).

74 Pub. L. 88-352, tit. VII, 78 Stat. 253 (1964) (codified as amended at 42 U.S.C. $\S$ 2000e to 2000e-17 (1976 \& Supp. V 1981)). 
tiff was not qualified for the employment he sought. Plaintiff submitted no materials in opposition to the motion. The court granted the motion and filed a memorandum indicating the facts that it had determined to be beyond triable issue, including the fact that plaintiff had filed no written application and the fact that he was not qualified for the position he sought. Plaintiff did not appeal. Instead, he submitted to defendant a written application, which was denied, and then filed a new suit. The defendant moved to dismiss this suit on the ground of res judicata. The motion was granted, the action was dismissed, and the plaintiff appealed. ${ }^{75}$

The court of appeals reversed. Judge Leventhal reasoned that although it was unnecessary to accept the doctrine of Halpern $v$. Schwartz as a universal proposition, it should be applied in circumstances in which one and only one of two independently sufficient determinations would constitute a bar to a second suit. ${ }^{76} \mathrm{He}$ noted that as a technical matter the second suit was on a different cause of action, but as a practical matter it was a continuation of the original litigation. ${ }^{77}$ Viewing the suit in this manner, Judge Leventhal read the judgment as resting on two independently sufficient grounds-failure to apply (which would not bar a second suit after application and denial) and unemployability (which would). ${ }^{78}$ He likened the failure to apply to a failure to exhaust extrajudicial remedies, which would bar recovery based on the original incident but would not preclude refiling after exhaustion. ${ }^{79}$

It is not easy to follow Judge Leventhal's reasoning. Having found it unnecessary to accept the full implications of Halpern $v$. Schwartz, he also found it unnecessary to express an opinion on the Restatement (Second) extension of Halpern to the doctrine of bar. This left Stebbins suspended precariously between the two.80

7s 481 F.2d at 505-06.

76 Id. at 508.

77 Id. at 509.

78. Id. at 508 .

78. Id. at 509 \& n.19.

0 The filing of a written application is clearly not a statutory prerequisite to a Title VII suit. And, with deference, the analogy to exhaustion of extrajudicial remedies is thin. The suit charged refusal to hire in violation of the Civil Rights Act of 1964, and if the determination that plaintiff had refused to file a written application was an independently sufficient ground for summary judgment at all, it was because refusal to hire could not be shown without application and denial, or because the flouting of the defendant's personnel practices supplied a reason for the refusal other than the plaintiff's race. Viewed in this way, the judgment based on failure to file the application would be as much a judgment on the merits of the claim as a judgment based on unemployability. It would bar a second action on the same cause, but of course would not bar an action based upon a later refusal to hire. The second suit, however, would be a wholly different cause, based on its own facts, and 
Perhaps the best way to analyze the litigation is to read the first suit's determination that the plaintiff did not file an application as establishing that the defendant had not refused to hire him. Since the defendant could not have denied the plaintiff employment on the basis of his race if it had not denied him employment at all, the judgment is on the merits and is a bar to a second action based on the alleged refusal. The determination that the plaintiff is unemployable, however, based on after-acquired information gleaned from the answers to his deposition, deals with the hypothetical question of whether, were he to apply, there would be reasons other than race for denying him employment. Viewed in this light the finding on employability was not an independently sufficient ground for the judgment on the first claim presented by the plaintiff, is unnecessary in the conventional sense, and therefore cannot bar his second claim. ${ }^{81}$

Apart from bankruptcy cases like Halpern, which arise in the context of a single case broken up by statute into a series of independent proceedings, and cases like Stebbins, in which the second action charges a wrong subsequent to judgment in the first, the rather broad contemporary view of "claim" or "cause of action,"82 coupled with the compulsory counterclaim rule, ${ }^{83}$ limit sharply the circumstances in which collateral estoppel is pleaded both by and

would not relate back. Since it was adjudged that no wrong was committed, there could be no "remedies" to exhaust, judicial or extrajudicial. If in such a case a determination in the first suit of a reason, other than failure to apply, why there was no violation of the statute does not trigger collateral estoppel in the second suit, it is difficult to distinguish Stebbins from a total acceptance of Halpern, for no judgment bars (in the sense of res judicata) a later action based on facts that take place after it is rendered. On the other hand, if the case is viewed as one in which the first action was premature or dismissed under the exhaustion doctrine, the case is very difficult to distinguish from the rule set forth in $\S 20(2)$ of the Restatement (Second).

s1 The defendant may plead (a) that it did not refuse to hire the plaintiff, and in the alternative (b) that it refused to hire him for a reason other than his race. See FED. R. Crv. P. 8(e)(2). But the fact that he may plead in the alternative does not mean that a judgment can be based on antithetical alternatives.

82 The trend toward a broad definition of claim for res judicata purposes was noted by the Supreme Court in Blonder-Tongue Laboratories, Inc. v. University of Ill. Found., 402 U.S. 313, 327 (1971). The Restatement (Second) defines a "claim" for purposes of merger and bar as "all rights of the plaintiff to remedies against the defendant with respect to all or any part of the transaction, or series of related transactions, out of which the action arose." RESTATEMENT (SECOND) OF JUDGMENTS \& 24(1) (1980).

${ }^{83}$ FED. R. Crv. P. 13(a) requires the pleader to plead as a counterclaim "any claim which at the time of serving the pleading the pleader has against any opposing party, if it arises out of the transaction or occurrence that is the subject matter of the opposing party's claim [with limited exceptions]." Thus normally the judgment would bar further litigation between the same parties in circumstances in which the facts determined in the first action would control the second. 
against a party to the first action. The most significant area in which the question arises is, perhaps, the case of serial obligations arising out of a continuous relationship, such as successive duties under a continuing contract, or obligations to pay interest installments on a note or redeem interest coupons on a bond. ${ }^{84}$ Though all the obligations arise out of the same transaction, they accrue over time. Thus, for purposes of the doctrine of merger, at least, they must be treated as different claims or causes of action. ${ }^{85}$ It is such a case that the Restatement (Second) has selected to exemplify the application of the Halpern doctrine to the doctrine of "issue preclusion." Plaintiff sues defendant for an accrued interest installment on a note. Defendant pleads two defenses: that his signature on the note was procured by plaintiff's fraud and that plaintiff has executed a valid and outstanding release of the obligation to pay interest. ${ }^{86}$ Under the Restatement (Second) view, a judgment for the defendant on findings of both fraud and release ought not to preclude the plaintiff from relitigating the issue of fraud in a later suit against the defendant for the principal sum. ${ }^{87}$

In such a case, there is no question of prematurity of the suit and no choice between a judgment on the merits and a dismissal without prejudice. The plaintiff's claim is ripe and must be decided now, and the defense of fraud goes directly to the merits of the claim. The defendant is under no less compulsion to present his fraud defense than he is in the case of the premature contract suit. $^{88}$ As in the case of the premature suit, the two defenses are not easily mixed up, either at trial or on appeal, ${ }^{80}$ nor is the effect of the determination of fraud ambiguous. ${ }^{90}$ The time and place of the trial have been selected by the plaintiff. He has had fair notice

84 See Restatement (Second) of Judgments § 24 comment d (1980).

es It would be possible, of course, to treat the first breach as accelerating all obligations, but it would be very inconvenient. The matter is handled by the Restatement (Second) through a "pragmatic[]" definition of "transaction" and "series of connected transactions," which takes into account "whether their treatment as a unit conforms to the parties" expectations or business understanding or usage." Id. § 24(2).

so $I d$. $\$ 27$ comment $i$, illustration 15 .

87 Id.

so If he omits the fraud defense and loses on the issue of release, he will be cast in immediate judgment for the interest, which, if the fraud defense is good, he does not owe. If he omits the defense of release, and loses on the fraud defense, he will be cast for the interest installment and estopped on the issue of fraud in subsequent litigation.

so The defenses involve different instruments executed at different times and dealing with different subject matter; it would be next to impossible to confuse them.

90 Fraud in inducing the defendant's signature goes plainly to all obligations under the instrument, and the circumstances alleged to constitute fraud must be pleaded with particularity. Fed. R. Crv. P. 9(b). 
of both defenses and there has been a plenary trial. There appears to be no reason why the double defense in any way deprives the plaintiff of his full day in court or should confer on him a reprieve from issue preclusion.

\section{Equitable Defenses}

For the reasons stated, if the Halpern-Restatement (Second) formulation worked in practice as the draftsmen of the Restatement apparently believed it would work, it would be thoroughly undesirable as applied either to the doctrine of bar or to estoppel inter partes. In both illustrations given by the Restatement (Second), the defendant has pleaded fraud in the inducement as a defense, in the one case as a defense in an action for breach of contract, ${ }^{21}$ in the other as a defense in an action for an interest installment on a note..$^{82}$ In either case the defendant could present his allegation of fraud in an independent suit for rescission or cancellation. ${ }^{93}$ In the federal courts after $1915,{ }^{94}$ such a claim can be pleaded as a defense or counterclaim in an action at law, and with the merger of law and equity under the Federal Rules of Civil Procedure, it may be so pleaded in a civil action. ${ }^{95}$ Accordingly, if the defendant wishes to be sure that a determination in his favor on the issue of fraud cannot be relitigated by the plaintiff in a second action on the same contract or the same note and also wishes to interpose a defense such as release of the interest obligation, he can answer, raising both defenses, and identify the fraud defense as a counterclaim for rescission, cancellation, or declaratory relief. ${ }^{96}$

The case of serial obligations is in this respect analogous to a suit for patent infringement. In such a case a defense of noninfringement, if established, defeats only the plaintiff's claim, while a defense of invalidity, through the application of collateral estoppel, would preclude any future suit for infringement. If the defendant concedes infringement and defends on the ground of invalidity

91 Restatemant (Second) of Judgments $§ 20$ comment e, illustration 4 (1980).

22 Id. \& 27 comment i, illustration 15.

os 3 J. Pomeroy, A Treatise on EquTtY JuRIsPrudence $\S$ 910, at 574 (5th ed. 1941).

24 See Act of Mar. 3, 1915, Pub. L. No. 63-278, § 274b, 38 Stat. 956, 956 (codified at 28 U.S.C. $\$ 398$ (1934) (repealed as unnecessary after adoption of the FED. R. Crv. P.)).

os Indeed, it must be pleaded or lost. Fed. R. Crv. P. 13(a).

28 See 28 U.S.C. $\$ \S 2201,2202$ (1976 \& Supp. V 1981). Where the plaintiff has brought suit on the contract or note, there is no doubt that there is a sufficient controversy to sustain jurisdiction in an action for declaratory relief. See J. Moore, 6A Moore's Federal Practice I 57.23 (2d ed. 1982). 
alone, a counterclaim would be redundant and normally would not be permitted. ${ }^{97}$ If the defendant pleads both noninfringement and invalidity, however, he runs the risk that the court might dismiss for noninfringement and make no finding on the issue of invalidity. If, therefore, the dispute between the parties extends beyond the particular infringement alleged in the complaint, the counterclaim serves a purpose and can be pleaded, and a judgment for the defendant based on a finding of noninfringement does not moot the counterclaim. ${ }^{98}$

To return to the Restatement (Second) illustrations, ${ }^{99}$ the issue of fraud in the inducement, as a defense to an instrument that is the fons et origo of the obligation sued upon and that imposes additional obligations not yet matured, always goes beyond the particular obligation currently sought to be enforced by the plaintiff. By analogy to the patent cases, therefore, the defendant could always protect against the risk that the court might dismiss on the ground of release of interest and decline to decide the issue of fraud merely by labeling the fraud defense as a counterclaim.

If the defendant does identify his fraud defense as a counterclaim, and judgment is rendered for the defendant on the main claim on a finding of release of interest and also on the counterclaim on a finding of fraud, the plaintiff appears to be in substantially the same position in which he would have been had a single judgment been rendered for the defendant on grounds of both release and fraud. ${ }^{100}$ In some respects, under the Restatement (Second) rule, he is worse off, for the court of appeals no longer has the

" A counterclaim that adds nothing to the answer has been spoken of as "a wholly redundant flourish." Scruggs v. Casco Corp., 32 F. Supp. 625, 626 (D. Conn. 1940). See J. Moore, 3 Moore's Fed. Practice I 13.07, at 13-37 \& n.6 (2d ed. 1982).

* Altvater v. Freeman, 319 U.S. 359, 363, 365 (1943). Altvater was a suit in equity for specific performance of a license agreement, an accounting, and an injunction. The defendant answered pleading invalidity and filed a counterclaim for a declaration that the reissue patent was invalid, but if held valid the license agreement should be extended to cover it. The trial court held that there was no infringement, that the agreement had terminated, and that the reissue patent was invalid. The Eighth Circuit held that in view of the determination that (1) there was no infringement, and (2) the agreement was terminated, defendant's counterclaim was moot. The Supreme Court reversed. It found that defendant was manufacturing articles under the former license agreement other than those included in the charge of infringement, and therefore there remained a live controversy between the parties.

- REstatemant (Second) of Judgments $\$ 20$ comment e, illustration 4 (1980); id. $\$ 27$ comment $i$, illustration 15 . See supra notes $86-96$ and accompanying text.

${ }^{100} \mathrm{He}$ could appeal from the judgment on the main claim, the judgment on the counterclaim, or from both. Indeed, as a technical matter they would be parts of the same final judgment. See FED. R. Crv. P. 54(b). There would be no alteration in the issues or in the posture of the parties. 
option of ignoring the issue of fraud and affirming the judgment solely on the ground of release. The question arises, then, why it would be useful to force the identification of the fraud defense as a counterclaim.

At the trial court level, the distinction between adjudication of fraud as a defense and as a counterclaim is minimal. Since the Federal Rules of Civil Procedure provide that in either case the facts alleged to constitute fraud must be pleaded with particularity, ${ }^{101}$ the plaintiff would receive no additional information from the change in label. If the claim of fraud were identified as a counterclaim, the plaintiff would be required to file a reply. ${ }^{102}$ This might be of some advantage to the defendant, but it does not seem to aid the plaintiff. ${ }^{103}$ In any event, however one assesses the utility of a reply, it is clear that no reply would be required if solely the fraud defense were pleaded, and the fact that release of interest and fraud are pleaded in tandem gives a reply no additional utility.

The only visible argument in favor of requiring identification as a counterclaim lies in the fact that the estoppel on the judgment on the counterclaim would be mutual, whereas under conventional principles, estoppel based on findings would not: in a judgment for the defendant on the ground of release of the interest obligation, a finding of no fraud would not support the judgment, and therefore relitigation of the issue would not be precluded. ${ }^{104}$ Arguments for avoidance of estoppel on the ground of want of mutuality have not been much in favor in recent years. ${ }^{105}$ Nevertheless, the mutuality issue arises here in a context that differs in essential respects from the context of estoppel pleaded by a stranger. In the latter context, because due process considerations permit only nonmutual estoppel or none at all, it might be best to adhere to the mutuality rules. In the present case, however, one might selectively relax the conventional limitation of estoppel to findings necessary to the judgment, so that neither the defendant nor the plaintiff could relitigate the fraud issue. Without at this writing advocating selective relaxation, the writer believes that it would be distinctly preferable

101 Id. $9(\mathrm{~b})$.

102 Id. 7(a).

${ }^{103}$ The only thing that the reply would add would be a duty of the plaintiff to admit or deny the allegations of the counterclaim. This might result in some admissions on the part of the plaintiff.

104 Restatement (Second) of Judgments § 27 (1980); J. Moore \& T. CuRrier, supra note 1 , I 0.443 [5].

${ }^{105}$ See, e.g., Blonder-Tongue Laboratories, Inc. v. University of Ill. Found., 402 U.S. $313,320-27$ (1971). 
to the Halpern-Restatement (Second) formulation. ${ }^{108}$

\section{Collateral Estoppel Pleaded by Strangers: Defensive Use}

To take an example of estoppel pleaded by a stranger to prior litigation, suppose plaintiff, injured in an intersection collision, sues the operator of another automobile involved in the collision in a jurisdiction in which contributory negligence is an absolute defense and in which failure to stop at a stop sign is negligence per se. After a full trial at which evidence is presented by both sides on the question of whether plaintiff stopped at a stop sign before proceeding into the intersection, the jury returns a verdict for the defendant and answers special interrogatories finding that defendant was not negligent and that plaintiff was negligent in that he did not stop at the stop sign. No appeal is taken, and plaintiff files a second suit, this time against the city, alleging negligence in the placement of a construction sign in a position so as to obstruct the plaintiff's view of traffic proceeding on the intersecting highway. The city pleads the first judgment as an estoppel to deny contributory negligence.

It is unnecessary to discuss in general the merits of permitting a stranger to the prior litigation to plead collateral estoppel; like most other recent authority, the Restatement (Second) repudiates the mutuality requirement. ${ }^{107}$ Assuming that nonmutual estoppel is justified in any case, this case is close to the beau ideal. The first action was initiated by the party against whom the estoppel is asserted. He chose his adversary, the timing, and the forum. The issue was an essential element in the case. There was a full trial and it was contested and determined by the jury. The plaintiff had a right to appeal. The issue is identical in the first and second cases. The estoppel is pleaded defensively. The plaintiff is simply attempting, by shifting adversaries, to put the same issue before a

108 Such want of mutuality as there is in the case of multiple dispositive findings was not considered to violate the mutuality requirement even when the requirement was generally adhered to and may be said to follow logically from the principle that findings made against a prevailing party are not appealable and do not support an estoppel. See supra note 9. There is some contrary authority. See, e.g., Cold Metal Process Co. v. E.W. Bliss Co., 285 F.2d 231, 236-37, 239 (6th Cir. 1960). In the special circumstances of an equitable defense that could have been pleaded as a counterclaim, it would make considerable good sense to permit appeal and hold that the determination is conclusive on both parties. In this connection it should be noted that if the defense is such as is properly pleaded as a counterclaim, it is provided in FED. R. Crv. P. 8(c) that "the court on terms, if justice so requires, shall treat the pleading as if there had been a proper designation."

107 RESTATEMENT (SEcOND) OR JUDGMBNTS § 29 \& reporter's note (1980). 
second jury-just the sort of case that gave impetus to the abandonment of the mutuality requirement. ${ }^{108}$

Turning to the Halpern considerations, unless the issues of negligence and plaintiff's due care were separated and the issue of defendant's negligence tried first, determination of plaintiff's due care would be necessary to the disposition of the cause. The determination of relative fault is a daily task of courts and juries and a determination of sole fault does not appear to be any more unreliable than a determination of mutual fault.

The efficiency considerations that underlay the Halpern decision and were found to be "of critical importance" by the Restatement (Second) reporters ${ }^{109}$ are perhaps more recognizable in this sort of case than they are in the case of serial obligations arising out of a single instrument or agreement. It is true that if plaintiff has no ground for appealing the determination that defendant was not negligent, any appeal he might take can be characterized as taken for the purpose of relief from a finding that would form the basis for an estoppel, should he bring a second suit against a different defendant. But, as in the case of serial obligations, it cannot be viewed as merely a hedge against speculative collateral litigation. If the plaintiff does not believe that he can win on both grounds he will not appeal unless he intends to cast around for a second adversary. While the necessity to appeal to rid himself of the estoppel no doubt adds to the cost of his pursuit of a judgment, and this cost will be weighed in the balance against his chance of ultimately prevailing, it is a cost that normally he could have avoided by joining the second adversary in the first suit.

In this connection it is important to note that the Restatement (Second) takes the view that on appeal from a judgment resting on more than one ground, if the appellate court affirms on one ground and refuses to reach the others, only the ground on which the judgment was affirmed will bottom a collateral estoppel. ${ }^{110}$ This position eviscerates the Halpern argument predicated on the deterrence of appeals. To take the Restatement (Second) illustration, ${ }^{111}$ no holder of a note adjudged unenforceable because of fraud would forgo appeal merely because he fears the appellate

${ }^{108}$ See Bernhard v. Bank of Am. Nat'I Trust \& Sav. Ass'n, 19 Cal. 2d 807, 812, 122 P.2d 892, 894 (1942). See also Blonder-Tongue Laboratories, Inc. v. University of Ill. Found., 402 U.S. 313, 323-24 (1971) (approving the Bernhard abandonment of the mutuality requirement).

109 See Restatement (Second) of Judgments § 20 comment e (1980).

110 Id. § 27 comment o. See supra note 29.

111 Restatement (Second) of Judgments § 27 comment i, illustration 15 (1980). 
court will find release of the interest obligation, unless the principal sum is not worth the cost of pursuing appeal. Moreover, if appellate pretermission of the fraud issue would result, in effect, in vacating the finding of fraud, the only extent to which he may be said to be discouraged from appealing lies in the cost of appeal without assurance of a final judgment. But many, if not most, appeals are directed at obtaining reconsideration rather than final disposition, and the plaintiff in the Restatement (Second) illustration could in no event obtain a final judgment for the principal sum of the note because his cause of action has not yet accrued.

Indeed, the Restatement (Second) position on the effect of appellate disposition appears to turn the Halpern reasoning upside down. In the Restatement (Second) illustration, if the plaintiff believes that he can prevail on appeal with respect to the release issue but doubts that he can overturn the determination of fraud, he will be encouraged to forgo the interest to buy another chance to litigate fraud. And the less complaint he has about the trial of the fraud issue, the more attractive this course would be. Similarly, in our hypothetical tort case, the plaintiff with a good chance of upsetting the finding of no negligence on the part of the defendant and a doubtful chance of disturbing the finding of contributory negligence would be encouraged to forgo appeal and to shift adversaries. Thus under Judge Smith's analysis in Halpern, the deterrence to appeal lies in the fear that the appellate court might not reach the ground on which estoppel would be based; ${ }^{112}$ under the Restatement (Second) solution, it lies in the fear that it might. The more correct and unassailable this ground is, the more likely it is that the plaintiff will disconnect and start over.

Unlike the case of estoppel inter partes, in which the defendant's self-interest assures that he will not ignore on appeal the ground that will have the broader effect, the case of estoppel in subsequent actions with strangers does exemplify Judge Smith's concern over the want of truly adversary posture on appeal. If, in our case, the plaintiff should concede defendant's want of negligence and brief and argue only the issue of his own due care, the defendant would have scant incentive to argue the issue.

But also unlike the case of estoppel inter partes, which serves to protect the parties from the necessity to relitigate issues that have been adjudicated between them, the extension of collateral estoppel to litigation with persons not party to the first record is 
based largely on system convenience. If a stranger is denied the benefit of an estoppel, he is not twice vexed or required to relitigate any issue; he must simply make his defense in the same fashion in which he would have made it had he been sued first. Thus the extension of collateral estoppel to litigation with strangers serves mainly the public policy of reducing litigation. ${ }^{113}$ It proceeds on the principle that one full and fair opportunity to litigate an issue is all that fairness requires and all the system can afford. ${ }^{114}$ Any want of adversary posture in an appeal from a finding of plaintiff's want of due care does not impair his full and fair opportunity to litigate; the absence of argument in opposition would inure purely to his benefit. But since the extension of estoppel to such cases rests largely on the ground of savings to the system, arguably it should not be carried into areas in which no savings can be realized. Thus if it is true that its application to multiple findings would produce such a volume of appeals taken purely in preparation for litigation with strangers as might be expected to cancel out any savings, it might be sensible to preserve the mutuality requirement in this particular instance.

Calculus of this sort is necessarily speculative, but it appears quite unlikely that the extension of the conventional rule regarding multiple sufficient findings to defensive estoppel pleaded by a stranger would produce any appreciable volume of appeals that would not be taken in any event. The circumstances in which the question can arise are limited to cases in which (1) the plaintiff's claim contains two elements, each necessary to recovery, one of which is related only to the present claim and the other of which is related to that claim and a potential claim of the plaintiff against another defendant, and the plaintiff fails to establish either element, or (2) the defendant pleads two defenses in the same fashion to the present claim of the plaintiff and a potential claim against another defendant, and the defendant establishes both defenses. Further, if both determinations are vulnerable on appeal the plaintiff can be expected to appeal and if the common determination is not vulnerable, he can be expected to acquiesce in the judgment and pursue the matter no further. Thus cases in which the plaintiff would seek to overturn a finding without seeking reversal of the judgment on the original claim are necessarily limited to those in which the individual element or defense is unassailable and the

113 See Blonder-Tongue Laboratories, Inc. v. University of Ill. Found., 402 U.S. 313, 328 \& n.18 (1971).

216 Id. 
common one vulnerable. Such cases do not arise very often. ${ }^{115}$ Under the Restatement (Second) formulation, to avoid this largely academic problem, the plaintiff would be permitted to relitigate the common element or defense against any number of blameless defendants so long as he continued to lose on both issues. Such a rule would plainly discourage joinder of defendants, which ought to be encouraged, and encourage dogged pursuit of a hopeless claim, which ought to be discouraged.

In formulating the Restatement (Second) position, the reporters referred to the matter as "difficult," and conceded that case by case analysis would reveal cases in which a balancing of the considerations would point to estoppel, but went on to suggest that in most instances the question would be close, and therefore expressed a preference for the certainty of a uniform rule. ${ }^{116}$ This approach is, of course, squarely opposed to most modern-day developments in the area of collateral estoppel, and indeed to the general cast of the Restatement (Second) itself. ${ }^{117}$ In cases in which the plaintiff did not have a full and fair opportunity to litigate an issue, the determination of the issue, under modern doctrine, does not constitute an estoppel in an action on a different claim or cause of action. ${ }^{118}$ And in the case of a judgment in the federal courts, at least, any inability to obtain appellate review is a factor to be taken into consideration in determining what is full and fair. ${ }^{119}$ There may be cases of multiple independently sufficient holdings that fall outside the boundaries of what is full and fair opportunity, and some cases may be "close." But with the general shift to consideration of individual cases, to pick out this remote little corner as requiring the certainty and predictability of a uniform rule borders on the whimsical.

\section{E. Collateral Estoppel Pleaded by Strangers: Offensive Use}

In many jurisdictions, including the federal, collateral estoppel may be pleaded by a stranger in support of a claim against a party

11 In Halpern v. Schwartz, Judge Smith, after "an exhaustive search," found three cases between 1866 and 1970 which he took to be directly on point. 426 F.2d at 107 n.4.

13 Restatement (SEcond) of Judgments $§ 27$ comment i (1980).

11 See, e.g., $\$$ 28(5), 29(8) (suggesting a balancing approach is often necessary).

118 Blonder-Tongue Laboratories, Inc. v. University of Ill. Found., 402 U.S. 313, 328-50 (1971).

119 See Standefer v. United States, 447 U.S. 10, 23 \& n.18 (1980). The Restatement (Second) states that a legal right to appeal or other form of appellate review should be a precondition to "issue preclusion." Restatement (Second) of JudGMenTs § 29(1) (1980). 
to the prior litigation. ${ }^{120}$ The Restatement (Second) supports this view. ${ }^{121}$ The further one departs from the original limitations imposed upon collateral estoppel, however, the more attenuated are the arguments for its application. In adopting the position that a stranger may make offensive use of a judgment in his subsequent suit against a party, the Supreme Court recognized that such an extension of the doctrine would give rise to cases in which the party to the litigation had a full and fair opportunity to litigate, but in which nevertheless it would be unfair to preclude relitigation. ${ }^{122}$ It found, however, that on balance it was better generally to adopt the doctrine of offensive use of estoppel by strangers and emphasize the broad discretion of the district courts to permit relitigation in circumstances in which the preclusion would be unfair. ${ }^{123}$ The courts have recognized that the nature of a determination as one of multiple independent bases for the judgment is a factor to be taken into account in the exercise of the district court's discretion.

In Hicks v. Quaker Oats Co., ${ }^{124}$ the defendant employer notified the employees in certain job classifications that it had introduced a new retirement plan. Under the new plan, the employee, upon reaching the age of sixty, would be put on inactive status. From then until his full retirement at sixty-five, the employee, under the terms of inactive status, would remain available for special assignments, but would be permitted to accept other employment deemed by the defendant not to be competitive with its business. During this period the employee would receive half the amount of his previous salary. ${ }^{125}$ One employee, who was fiftyseven at the time the new plan was announced, at the instruction of the defendant trained his successor and paid his successor a portion of his own salary. Six months before the employee's sixtieth birthday, defendant sold the division for which the employee worked and terminated his employment. The employee accepted employment with the new owner, but was required to retire at sixty-two. The employee sued the defendant and the new owner. The court dismissed the claim against the new owner but entered

${ }^{120}$ Parklane Hosiery Co. v. Shore, 439 U.S. 322, 331 (1971). The Court chose "not to preclude the use of offensive collateral estoppel, but to grant trial courts broad discretion to determine when it should be applied." Id.

121 Restatement (Second) of Judgments $\$ 29$ comment b (1980).

122 Parklane Hosiery Co. v. Shore, 439 U.S. 322, 330-31 (1971).

123 Id. at 331.

124662 F.2d 1158 (5th Cir. 1981).

12 For a comprehensive discussion of the retirement plan, see $i d$. at 1159-60. 
judgment against defendant. The judgment was rendered on the ground that the notice of the new retirement plan had the effect of changing the at-will employment of the plaintiff into a contract of employment for the five-year period between ages sixty and sixtyfive, and the termination of plaintiff's employment constituted a breach of the contract. The court also rendered judgment on the ground that plaintiff's training his successor and paying his successor out of his own pocket constituted injurious reliance. The defendant did not appeal. ${ }^{128}$

Subsequently fourteen other employees who had been terminated prior to their sixtieth birthdays sued defendant for breach of contract. After some vacillation the district court entered summary judgment for the plaintiffs on the ground that the defendant was estopped to deny the existence of a bilateral contract arising out of the notice of the plan and its acceptance. ${ }^{127}$ The court of appeals held that under the total circumstances the court's refusal to permit reexamination of the bilateral contract theory constituted an abuse of discretion. It rejected the contention that collateral estoppel was not applicable to questions of law, ${ }^{128}$ declined to hold that the fact alone that a decision is rendered on behalf of a particularly attractive plaintiff precludes an estoppel, ${ }^{129}$ and did not adopt the Restatement (Second) rule of multiple grounds. ${ }^{130}$ In the instant case, however, the court refused to impose estoppel. It found that the claim of the plaintiff in the previous case, who had been terminated only six months before his sixtieth birthday, was a particularly sympathetic one. Further, his claim was for about $\$ 35,000$, whereas the second case involved in excess of $\$ 400,000$. Finally, the holding in the first case was an alternative theory of liability, and the plaintiffs in the second action were strangers to the first litigation. ${ }^{131}$ These circumstances taken together, the

126 Id. at 1161-62.

${ }^{227}$ Id. at 1162-65.

128 Id. at 1166-67. The facts in the case were not in dispute. In the first case, the court read the defendant's letter as unambiguous. The court of appeals in Hicks disagreed with this reading and indicated that on remand the court should permit the introduction of extrinsic evidence on this subject. Id. at 1175-76.

138 Id. at 1172.

$130 \mathrm{Id}$. at 1168-70.

131 Id. at 1171-72. While the court did not commit itself to the Restatement (Second) rule in general, it found that the application of the rule is particularly appropriate in the case of offensive collateral estoppel by a stranger. It then proceeded to discuss the circumstances in terms of the "fairness" principles that form the basis for the exercise of discretion under the Parklane decision, noting that the alternative character of the holding "bolstered" the argument of unfairness. Id. at 1170. 
court of appeals reasoned, ${ }^{132}$ were enough to demonstrate unfairness in the use of estoppel within the discretionary rule laid down by the Supreme Court in Parklane Hosiery Co. v. Shore. ${ }^{133}$

The Hicks case no doubt falls within the "broad discretion" to deny the offensive use of estoppel by a stranger confirmed in Parklane. Moreover, the alternative nature of the holding asserted as an estoppel is, under the circumstances, an important feature of any unfairness that can be said to exist. ${ }^{134}$ The court properly rejected the argument that collateral estoppel could not be applied because the issue was one of law. ${ }^{135}$ Yet the character of the issue is not wholly irrelevant. The fact that injurious reliance was proved and held to be an independent consideration rendered the holding that the letter announcing the new retirement plan constituted an offer for a bilateral contract, which plaintiff accepted by continued employment, strangely hypothetical. ${ }^{136}$ The case in which the judgment rests on independent factual determinations is a different one. In our earlier hypothetical of seriatim actions for personal injury, ${ }^{137}$ for example, suppose that after a determination that the defendant was negligent and the plaintiff was not proceeding with due care, the operator of a third car should sue the plaintiff for injuries arising out of the same accident, and the plaintiff should deny that he failed to stop at the stop sign. The argument for per-

132 Id. at 1171-73.

1ss 439 U.S. 322 (1971); see supra note 5.

134 There were three classes of employees involved in the overall dispute. There were those who had reached 60 on the day the division was sold. There was the plaintiff in the first case, who was six months from his sixtieth birthday and had trained his successor, paying his successor from his own funds. And there were others who had not yet reached 60 . It was defendant's contention that the term "eligible employee" in the letter announcing the program referred to persons who had reached 60 at the time the business was sold. $662 \mathrm{~F} .2 \mathrm{~d}$ at 1175. Defendant conceded its liability to them and they do not figure in the litigation. The plaintiff in the first case had prevailed on the issue of injurious reliance. The judgment was for $\$ 35,000$. The plaintiff had no interest in the basis of the judgment and could neither lose nor gain any advantage by its disposition on appeal. If the defendant appealed and conceded the alternative remedy, therefore, there was a distinct possibility that the appeal would be dismissed as moot. See supra note 64 . Thus to obtain review of the holding on the bilateral contract ruling, the defendant would have had to brief and argue both issues, and if he won on the contract issue, the plaintiffs in the second suit, not having been parties, would not have been bound by the decision. Thus the considerations that Judge Smith discussed in Halpern do weigh against an estoppel. See supra notes 18-32 and accompanying text.

${ }^{135} 662$ F.2d at 1166-67 (discussing Montana v. United States, 440 U.S. 147, 162 (1979)).

${ }^{136}$ Since the plaintiff in the first action presented a case factually distinct from the plaintiffs in the second action, and the facts were not in dispute, it was unnecessary to determine whether the plaintiff in the first action would have prevailed had some of the facts in this case been different.

${ }^{197}$ See supra notes $107-08$ and accompanying text. 
mitting the estoppel would be compelling. In the Hicks case, the facts were fixed and the second court applied a broader reading of the law than was necessary to support the judgment. In the hypothetical, the facts were necessarily determined and the plaintiff seeks simply to play roulette with the jury.

In sum, while the application of the Restatement (Second) rule on multiple grounds would be easier to justify in cases in which a stranger seeks to use estoppel to establish his claim, the "broad discretion" to deny estoppel in such circumstances makes such a rule unnecessary.

\section{Conclusion}

Halpern v. Schwartz ${ }^{138}$ was decided in 1970, a year before the marked shift in federal cases in the direction of analysis of collateral estoppel as a matter of full and fair opportunity to litigate. The rule in Halpern was unnecessarily broad, and the considerations recited in its justification plainly not universally present. To the extent the case was intended to state a universal rule to be applied mechanically to multiple determinations each sufficient to support the judgment, it was later confined to its facts in the circuit in which it was decided, ${ }^{139}$ and has been approached with great caution elsewhere. To the extent that it dealt with the special problem of successive proceedings under sections $3 a, 60,70$, and 14(c) of the Bankruptcy Act of 1898, its significance died in 1978. ${ }^{140}$ Unfortunately, there was a star-crossed love affair between the Restatement (Second) and Halpern. The Halpern "reasoning" was embraced with unflagging fervor and applied to produce a formulation covering not only collateral estoppel across the board-inter partes and with strangers, defensive and offensive-but was extended to bar as well as estoppel. As applied to the doctrine of bar, application of the Restatement (Second) formulation would be inefficient, often patently unfair, and would introduce uncertainty where certainty is crucial. As applied to collateral estoppel between parties to the original litigation, in the very illustration given in the Restatement (Second) it would produce little more than a pleading trap, but to the extent that it had any

128426 F.2d 102 (2d Cir. 1970). (1977).

130 See Williams v. Ward, 556 F.2d 1143, 1154 (2d Cir.), cert. dismissed, 434 U.S. 944

${ }^{140}$ The Bankruptcy Reform Act of 1978, Pub. L. No. 95-598, 92 Stat. 2549 (codified as Title 11 of U.S.C. (Supp. V. 1981)), revised Title 11 of the United States Code. The reform act took effect on October 1, 1979. See 11 U.S.C.A. preface (West Supp. 1982). 
further effect it would involve the same inefficiency and unfairness that it would have in its application to the doctrine of bar. As applied to the defensive use of estoppel by a stranger, it would merely preserve an odd little corner of the mutuality doctrine without special justification. In the case of offensive use by a stranger, though the fact that the first judgment rests on two independent grounds may be a factor in the discretion to reject the use of estoppel, the Restatement (Second) "uniform rule" is both unnecessary and out of keeping with the Supreme Court's resolution of the problem in Parklane Hosiery Co. v. Shore. ${ }^{141}$ 